\title{
TAFSIR AYAT-AYAT AL-QURAN BERKENAAN PENJAGAAN ALAM SEKITAR DAN ANALISIS ISU-ISU ALAM SEKITAR DI MALAYSIA
}

\author{
INTERPRETATION OF THE QUR'ANIC VERSES ON \\ PRESERVATION OF ENVIRONMENT AND ANALYSIS OF \\ ENVIRONMENTAL ISSUES IN MALAYSIA
}

\section{'Imaaduddin Abdul Halim', Noor Shakirah Mat Akhir** \\ ${ }^{* *}$ School of Humanities. Universiti Sains Malaysia. 11800. Pulau Pinang. Malaysia. \\ Email: *imad1589@yahoo.com}

\begin{abstract}
Khulasah
Dewasa ini pelbagai isu berkenaan alam sekitar dibincangkan sama ada kepentingan, kemusnahan dan cara-cara mengatasi kemusnahan alam sekitar. Ia merangkumi perbincangan dari sudut konvensional mahupun dari perspektif Islam. Kemusnahan alam sekitar pada masa kini semakin menjadi-jadi hasil daripada pemerasan sumber alam yang tidak terkawal oleh manusia demi mencapai keuntungan. Jika dilihat kepada kemajuan teknologi yang terdapat di Malaysia sekarang, perkara seperti ini sepatutnya tidak berlaku jika penggunaan akal yang maksima oleh manusia diasaskan dengan iman. Manusia mampu untuk membezakan antara pro dan kontranya sekiranya sumber alam digunakan dengan rakus. Namun sifat tamak yang menguasai mampu untuk mengaburi pandangan segelintir masyarakat tanpa memikirkan kesannya dikemudian hari. Dari perspektif Islam dengan menjadikan al-Qur'an sebagai rujukan mutlak, kemusnahan alam sekitar sebenarnya mampu dielakkan jika setiap individu tahu amanah atau tanggungjawabnya sebagai khalifah di bumi ini. Persoalannya, adakah terdapat ayat khusus dalam al-Qur'an yang menerangkan berkenaan penjagaan alam sekitar? Adakah pengajaran dari al-Qur'an mampu memberi
\end{abstract}


penyelesaian kepada krisis alam sekitar di Malaysia? Berdasarkan kaedah literatur dan analisis kandungan, perbincangan ini akan menjawab persoalan-persoalan tersebut. Dapatan perbincangan melalui pentafsiran ayat-ayat terpilih berkaitan penjagaan alam sekitar mendapati terdapat pelbagai ayat al-Qur'an yang menekankan konsep melestarikan alam.

Kata kunci: Penjagaan, alam sekitar, al-Qur'an, isu alam sekitar, Malaysia.

Abstract
Nowdays, various environmental issues have been
discussed which include its importance, destruction
or the ways of preventing any environmental
destruction. The current paper will explore these
issues from both the conventional and the Islamic
perspectives. Environmental distruction in the present
time are becoming more common due to the
uncontrolled exploitation of natural resources by
human beings in order to generate profits. In view of
the increasing of the technological advances in
Malaysia presently, the above matter should not
happen if people's intellect is founded on faith.
People are able to distinguish between positive and
negative consequences of voraciously exploiting
natural resources. However, the greed that engulfs
some people, has obscured these people to think of
the consequences in the future of their acts. From the
Islamic perspective with the Quran as the ultimate
reference, the environmental destruction could
actually be prevented if individuals are aware of his
or her trustworthiness or responsibility as His
caliphate in the earth. The questions here, is there any
particular verse in the Holy Quran that explains the
environmental preservation? Is the teaching of the
Holy Quran could provide solutions to the
environmental crises in Malaysia? The current study
provides explanations to the above questions based
on the literature surveys and the content analysis
method. The findings of the interpretation of the


selected verses concerning the environmental preservation have identified that there are numerous verses in the Holy Qur'an which emphasize the concept of the preserving nature.

Keywords: Preservation, environmental, al-Qur'an, environmental issues, Malaysia

\section{Pendahuluan}

Kewujudan krisis alam sekitar yang melanda dunia pada hari ini sebenarnya telah wujud sejak abad ke-18 lagi. Kewujudan krisis ini adalah hasil daripada tercetusnya Revolusi Industri yang berlaku di Eropah. Revolusi ini yang bermula khususnya di England adalah satu perubahan ke arah mengeluarkan secara besar-besaran barangan keperluan manusia ${ }^{1}$ Aktiviti-aktiviti perindustrian ini telah menyebabkan berlakunya pengekploitasian sumber alam secara besar-besaran dan seterusnya membawa kepada krisis alam sekitar yang serius. Kesedaran secara langsung tentang krisis alam sekitar ini wujud apabila terbitnya sebuah buku iaitu Silent Spring pada tahun 1962. Buku ini dihasilkan oleh Rachel Carson yang juga merupakan seorang saintis. Ia telah berjaya menyedarkan masyarakat dunia berhubung dengan krisis alam sekitar yang semakin meruncing ketika itu ${ }^{2}$.

Tambahan pula, kebelakangan ini terdapat isu-isu alam sekitar yang semakin serius wujud hasil daripada berlakunya penggunaan dan eksploitasi sumber alam yang tidak terurus. Kesan daripada eksploitasi ini telah menyebabkan berlaku pencemaran alam sekitar dan ini boleh dirasai apabila pada pertengahan tahun 2010 terjadi pertambahan suhu dunia secara mendadak kerana penipisan lapisan ozon bumi. Peningkatan suhu dunia ini telah meningkat sebanyak dua darjah dan telah

\footnotetext{
${ }^{1}$ Mohd Zuhdi Marsuki \& Amir Saifude Ghazali, Etika Alam Sekitar daripada Perspektif Islam, Timur \& Barat (Bentong: PTS Publications, 2002), 2.

${ }^{2}$ Ibid, 4.
} 
menyebabkan banyak negara mengalami kepanasan yang melampau dan ia juga turut dirasai di Malaysia ${ }^{3}$.

Di Malaysia sendiri, terdapat pengeksploitasian sumber alam yang melampaui batas sehingga menyebabkan hilangnya kebersihan alam sekitar. Ini ditambah pula dengan kewujudan segelintir masyarakat yang sanggup melanggar undang-undang semata-mata untuk memerah sumber alam. Contohnya pencerobohan 40 hektar tanah di Janda Baik, Pahang sedangkan kawasan hutan ini telah diwartakan sebagai hutan simpan. Pencerobohan tanah ini didalangi oleh sindiket yang mengupah warga asing untuk mengusahakan secara haram tanaman sayur-sayuran dan buah-buahan. Sindiket ini telah lama beroperasi di kawasan hutan ini sehinggakan mereka telah dapat menuai hasil tanaman itu sendiri ${ }^{4}$.

Walaupun kaedah ini dapat memanfaatkan fungsi tanah, tetapi pencerobohan yang dilakukan oleh mereka sebenarnya merosakkan alam sekitar itu sendiri. Ini disebabkan kawasan hutan yang diceroboh itu berada dalam pengawasan dan penjagaan untuk warisan ketika banyak kawasan hutan diteroka untuk tujuan pembangunan. Namun begitu, al-Qur'an sebagai rujukan utama dalam Islam sebenarnya telah menyediakan semua jawapan kepada permasalahan kehidupan manusia. Oleh itu ayat-ayat al-Qur'an perlu sentiasa dijadikan kajian dan rujukan termasuklah dalam menangani isu-isu alam sekitar.

Artikel ini akan membincangkan aspek penjagaan alam sekitar dalam al-Qur'an. Kaedah Tafsir al-Mawdī' $\bar{i}$ akan diguna pakai dalam mengenal pasti ayat-ayat penjagaan alam sekitar dalam al-Qur'an dengan merujuk

3 Ishak Jaino, Pemanasan Global, laman sesawang Dspace, http://dspace.unimap.edu.my/dspace/bitstream/123456789/7862/1/Pem anasan\%20global.pdf, dicapai 17 April 2011.

${ }^{4}$ Lum Chee Hong, Janda Baik Kena Ceroboh, Berita Harian, 8 Ogos 2014, 10. 
kepada kitab Tafsir al-Misbah serta beberapa tafsir lain. Di samping itu, artikel ini juga akan membincangkan tiga aspek penting yang berkaitan dengan penjagaan alam sekitar iaitu aspek tujuan penciptaan manusia, aspek alMìzān sebagai konsep keseimbangan alam dan aspek takdir.

\section{Alam Sekitar}

Berdasarkan Akta Kualiti Alam Sekeliling Malaysia, alam sekitar atau persekitaran bermaksud faktor-faktor fizikal yang mengelilingi kehidupan manusia. Ia termasuk tanah, air, udara, iklim, bunyi, bau, rasa, faktor-faktor biologi dan juga fakta-fakta sosial ${ }^{5}$. Alam sekitar juga boleh didefinisikan sebagai ekosfera yang mengandungi ekosistem-ekosistem yang saling berinteraksi. Ekosistem pula terdiri daripada faktor-faktor biologi yang saling bergantung sesama sendiri, iaitu di antara faktor-faktor biologi dengan faktor-faktor fizikal ${ }^{6}$.

Alam sekitar merupakan salah satu elemen penting yang perlu dibincangkan. Sumbernya berkait rapat dengan kehidupan manusia dan semua makhluk ciptaan Allah. Istilah alam sekitar merupakan istilah yang selalu digunakan untuk menggambarkan keadaan semua yang wujud di dunia. Istilah 'environment' dalam bahasa Inggeris merujuk kepada setiap benda yang berada berdekatan atau di sekeliling kita $^{7}$. Selain itu ia juga membawa maksud keadaan sekeliling atau lingkungan. Berdasarkan kepada terjemahan secara literal, maka perkataan 'alam sekitar' merujuk kepada apa sahaja yang melingkungi dan mengelilingi manusia.

${ }^{5}$ Norhibah Hasan Zawawi, Konsep Islam terhadap Pemuliharaan Alam Sekitar (Jabatan Perdana Menteri: Jabatan Kemajuan Islam Malaysia, 1999), 4.

${ }^{6}$ Ibid.

${ }^{7}$ Miranda Steel, New Oxford Dictionary, terj. Zubaidah Abdul Rahman (Shah Alam: Fajar Bakti Sdn. Bhd, 2004), 266. 
Namun begitu, istilah alam sekitar secara khususnya merujuk kepada fenomena fizikal. Fenomena fizikal ini termasuklah juga fenomena yang berkait dengan iklim dan cuaca $^{8}$. Istilah alam sekitar dalam bahasa Arab dikenali sebagai $a l-b \bar{i}$ 'ah yang bermaksud lingkungan, persekitaran atau keliling'. Istilah al-bīah menurut Lisān al-'Arāb bermaksud rumah sesuatu kaum yang terletak di suatu lembah. Selain itu ia juga boleh diertikan kelembutan sesuatu tempat kerana persekitaran yang elok ${ }^{10}$. Persekitaran juga boleh didefinisikan sebagai lingkungan hidup manusia. Lingkungan ini terhasil melalui nilai-nilai kehidupan yang mempunyai sumber-sumber untuk kehidupan seperti makanan, pakaian, perubatan dan juga tempat tinggal. Seterusnya terdapat interaksi dan hubungan sesama manusia dalam lingkungan ini ${ }^{11}$.

Alam berdasarkan perspektif al-Qur'an merupakan ciptaan Allah SWT dan ia dimiliki oleh Allah SWT. Ini berdasarkan surah al-Hajj ayat 64:

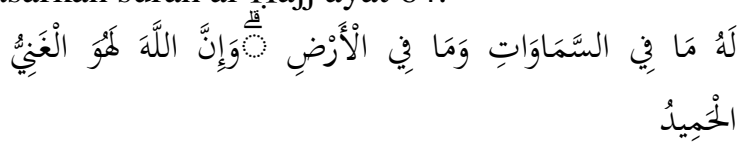

Terjemahan: Segala yang ada di langit dan di bumi adalah kepunyaan-Nya dan sesungguhnya Allah, Dialah jua yang Maha Kaya lagi Maha Terpuji.

Walaupun manusia mendiami alam ini dan menggunakan sumber-sumber yang terdapat di bumi ini, perlulah diingat bahawa segala yang terdapat di alam ini bukan milik mutlak manusia, tetapi ia dimiliki oleh

\footnotetext{
${ }^{8}$ Mohd Zuhdi \& Amir Saifude, Etika Alam Sekitar, 20.

${ }^{9}$ Mohd Khairi Zainuddin et.al., Kamus al-Miftah (Seremban: Al-Azhar Media, 2007), 385.

${ }^{10}$ Ibn Manzeur, Lisān al- 'Arāb, (Beirut: Dār al-Dar, t.t), 1:39.

11 Yūnus Ibrāhīm Aḥmad Mūzid, Al-Bìi ah fì al-Islām (t.tp: Dār alHamid, 2009), 31.
} 
pencipta alam ini iaitu Allah SWT. Manusia tidak boleh sewenang-wenangnya menggunakan sumber-sumber ini dengan melampaui batas.

Penjagaan alam sekitar juga dititik beratkan dalam Islam. Ini berdasarkan ayat-ayat al-Qur'an yang menyeru manusia untuk menjaga alam sekitar. Tambahan pula manusia dicipta dengan salah satu elemen alam iaitu tanah. Walaupun begitu, ayat-ayat yang terdapat dalam alQur'an ini tidak menyebut secara khusus cara-cara untuk menjaga alam sekitar ${ }^{12}$. Contohnya firman Allah dalam surah Hūd, ayat 61:

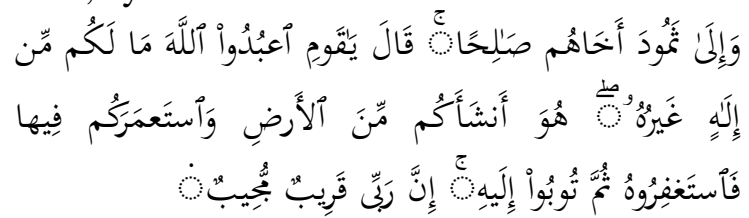

Terjemahan: Dan kepada kaum Thamud, Kami utuskan saudara mereka: Nabi Soleh. Dia berkata: "Wahai kaumku! Sembahlah kamu akan Allah! Sebenarnya tiada Tuhan bagi kamu selain daripadanya. Dialah yang menjadikan kamu dari bahan-bahan bumi, serta menghendaki kamu memakmurkannya.

Allah telah memberikan manusia itu tanggungjawab untuk memakmurkan alam ini dengan meramaikan para penduduk alam ini agar peranan sebagai pemakmur semakin mudah. Tambahan pula alam ini menawarkan pelbagai manfaat untuk kegunaan manusia agar memberi kesedaran terhadap keesaan Allah SWT. Dalam pada itu, Allah mempermudahkan lagi tugas manusia dengan memberi peluang untuk bertaubat dan memohon keampunan kepada Allah SWT sekiranya mereka melakukan kesalahan yang mengundang kemurkaan-Nya.

12 Dalam al-Qur'an tidak dinyatakan secara khusus atau terperinci kaedah menjaga alam sekitar namun terdapat banyak ayat-ayat alQur'an menyatakan secara umum gesaan memakmurkan alam. 
Peluang yang Allah berikan ini menunjukkan kasih sayang-Nya ditambah pula dengan janji Allah untuk merahmati dan memperkenankan doa-doa dipohon para hamba-Nya ${ }^{13}$.

Selain itu, al-Qur'an juga telah banyak menyentuh mengenai kerosakan dan pencemaran alam yang dikaitkan dengan perbuatan manusia. Antaranya dalam surah alRum ayat 41:

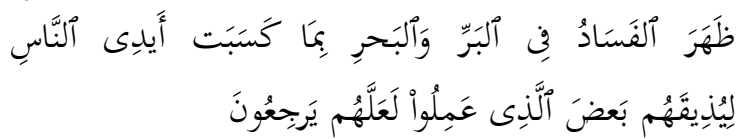

Terjemahan: Telah berlaku kerosakan di darat dan di laut kesan daripada perbuatan manusia, demikian (supaya Allah) merasakan kepada mereka terhadap (kerosakan) yang mereka lakukan, semoga mereka kembali bertaubat.

Menurut al-Qurțūbì, ulama berbeza pendapat dalam menafsirkan ayat di atas. Al-Qurțūbi memetik pandangan yang mengatakan kerosakan ini merujuk kepada perbuatan syirik. Manakala Ibn `Abbās merujuk kerosakan dalam ayat ini kepada pembunuhan Habil oleh Qabil. Selain itu terdapat pandangan bahawa kerosakan ini merujuk kepada kemarau dan hilangnya keberkatan di samping melakukan maksiat, merompak dan zalim. Begitu juga pendapat yang dilontarkan oleh `Atiyyah yang merujuk kerosakan kepada kurangnya pendapatan hasil laut kerana wujudnya bencana.

Rumusannya kerosakan-kerosakan ini membabitkan kerosakan rohani seperti melakukan syirik dan zalim manakala kurangnya hasil laut disebabkan bencana seperti wujudnya pencemaran dan sebagainya merujuk kepada

${ }^{13}$ Ibn Kathīr, al-Ḥāfiz Abī al-Fidā' Ismā'īil, Tafsīr al-Qur 'ān al- 'Ażìm, jil. 4 (Beirut: Dār al-Kutub al-Ilmiyyah, 1998), 286. Lihat juga Hamka, Abdul Malik Abdul Karim, Tafsir al-Azhar (Singapura: Pustaka Nasional Pte Ltd, 2007), 5: 3500. 
kerosakan fizikal ${ }^{14}$. Ayat 41 di atas jelas membuktikan kerosakan yang berlaku di darat dan di laut terhasil daripada perbuatan manusia itu sendiri. Ini secara tidak langsung menunjukkan walaupun tamadun manusia melebihi makhluk-makhluk ciptaan Allah yang lain, tetapi kerosakan di dunia ini terjadi disebabkan oleh kelompok manusia sendiri melalui pemerasan khazanah alam yang melampau.

Perbincangan mengenai alam sekitar banyak dibincangkan sama ada melalui media massa dan juga media cetak. Selain itu, terdapat pelbagai perbahasan dan perbincangan mengenai alam sekitar melewati pelbagai perspektif yang merangkumi aspek teoritikal dan juga praktikal. Ini termasuklah aspek penjagaan alam sekitar. Namun begitu, jika disoroti dengan lebih mendalam, kebanyakan langkah-langkah penjagaan alam sekitar tidak dikaitkan bersama hubungan manusia dengan penciptaNya. Kempen-kempen yang dilaksanakan tidak dikaitkan dengan landasan agama yang menekankan tiga aspek penting iaitu hubungan manusia dengan Allah SWT, hubungan manusia dengan manusia dan hubungan manusia dengan alam. Dalam mengaplikasikan kehidupan sebagai seorang Muslim, ketiga-tiga hubungan ini perlu diwujudkan dan dipelihara agar tidak terpesong daripada tujuan penciptaan manusia itu ${ }^{15}$.

Menurut Mawil Izzi Dien dalam membahaskan konsep alam sekitar dalam al-Qur'an, beliau menghuraikan bahawa alam sekitar merujuk kepada perkataan ma'āyish (tinggal). Istilah ini merujuk kepada persekitaran yang menjadi tempat tinggal yang mempunyai makanan dan mempunyai binatang serta

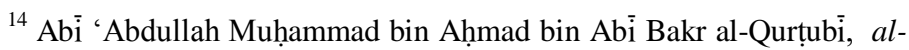
Jāmi ' li al-Aḥkam al-Qur'ān al-Karìm (Beirut, Lubnan: Mūassasah al-Risālah, 2006).

15 Firman Allah SWT: Kecuali jika mereka berpegang kepada tali (agama) Allah dan tali (perjanjian) dengan manusia. Ali 'Imran: 112. 
tumbuh-tumbuhan. Ketiga-tiga elemen ini saling bersangkut paut dan saling mempunyai perkaitan dalam kehidupan. Beliau juga menerangkan bahawa Allah mencipta alam sekitar atau bumi ini untuk manusia bersyukur $^{16}$ kepada Allah $\mathrm{SWT}^{17}$. Ini membuktikan bahawa kepentingan alam sekitar kepada manusia khususnya dan juga kepada makhluk-makhluk ciptaan Allah yang lain. Secara tidak langsung ia dapat melestarikan tamadun manusia.

Namun begitu, terdapat tiga aspek penting yang perlu diambil kira dalam usaha untuk melestarikan alam sekitar. Antaranya ialah tujuan penciptaan manusia itu yang berperanan penting untuk menjadi pentadbir dan pemakmur alam. Selain itu, perlu juga diambil kira konsep al-mízān atau keseimbangan kerana setiap penciptaan Allah SWT berkait rapat dengan keseimbangan (almizān). Melalui keseimbangan ini akan mewujudkan alam sekitar yang harmoni dan sejahtera. Namun begitu, keduadua aspek ini juga berkaitan dengan takdir Allah SWT. Takdir ini yang menentukan peranan manusia di atas muka bumi dan keseimbangan alam ini. Takdir yang telah ditetapkan oleh Allah SWT akan mencorakkan perjalanan alam termasuklah dalam aspek keseimbangan dan peranan manusia itu sendiri.

\section{Tujuan Penciptaan Manusia}

Dalam mewujudkan kelestarian tamadun manusia dari perspektif Islam, perlu diingat tujuan manusia itu dicipta. Tujuan utama manusia itu dicipta atas dua peranan penting iaitu sebagai khalifah Allah SWT dan juga hamba Allah SWT. Peranan ini telah dirakamkan dalam firman Allah berdasarkan surah al-Baqarah ayat 30 :

\footnotetext{
${ }^{16}$ Bersyukur di sini bermaksud kita tidak merosakkan alam sekitar dan memanfaatkannya untuk kelangsungan hidup.

17 Mawil Izzi Dien, The Environmental Dimensions of Islam (Cambridge: The Lutterworth Press, 2000), 24.
} 


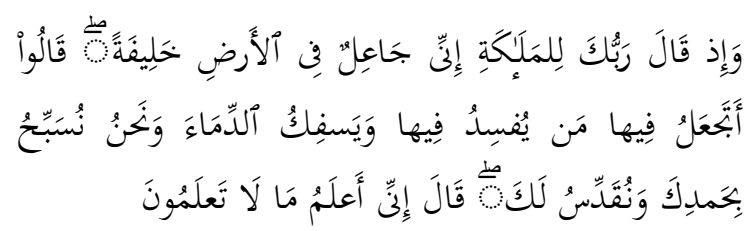

Terjemahan: Dan (ingatlah) ketika Tuhanmu berfirman kepada malaikat; "Sesungguhnya Aku hendak menjadikan seorang khalifah di bumi". Mereka bertanya (tentang hikmat ketetapan Tuhan itu Dengan berkata): "Adakah Engkau (Ya Tuhan kami) hendak menjadikan di bumi itu orang yang akan membuat bencana dan menumpahkan darah (berbunuh-bunuhan), padahal kami sentiasa bertasbih dengan memujiMu dan mensucikanMu?". Tuhan berfirman: "Sesungguhnya Aku mengetahui akan apa yang kamu tidak mengetahuinya".

Ibn Kathīr dalam menafsirkan ayat di atas menghuraikan persoalan yang telah diajukan oleh malaikat tentang peranan khalifah sedangkan mereka mengetahui peranan ini amat berat kepada manusia. Ini kerana manusia seperti yang diketahui oleh para malaikat merupakan makhluk yang suka kepada kezaliman dan kerosakan. Namun jawapan Allah kepada malaikat menggambarkan bahawa Allah mengetahui hikmah disebalik pemberian peranan khalifah ini kepada manusia.

Seterusnya menurut Ibn Kathïr lagi, walaupun golongan manusia ini terdorong ke arah kezaliman dan kerosakan namun terdapat kemaslahatan yang lebih besar lagi daripada kerosakan dan kezaliman yang dilakukan. Ini kerana, dalam kejahilan umat manusia ini, Allah telah menempatkan golongan para Nabi dan Rasul, șiddiqin, shuhadā', mukminin, para wali dan ulama untuk menjadi pembimbing kepada manusia dalam mentadbir dan menguruskan alam ini seperti yang dikehendaki oleh 
Allah SWT ${ }^{18}$. Melalui golongan inilah keistimewaan diberikan kepada umat manusia untuk berperanan sebagai khalifah.

Ayat al-Qur'an di atas jelas membuktikan peranan manusia yang diberi amanah oleh Allah SWT sebagai khalifah di bumi. Ini termasuklah dalam melaksanakan amanah untuk memelihara alam sekitar yang menjadi salah satu elemen yang penting dalam memberi kehidupan dan memelihara tamadun manusia itu sendiri. Seterusnya surah Al-Dhariyat ayat 56:

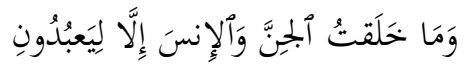

Terjemahan: Dan (ingatlah) Aku tidak menciptakan jin dan manusia melainkan untuk mereka menyembah dan beribadat kepadaKu"

Berdasarkan ayat di atas, Ibn Kathīr menghuraikan bahawa Allah menciptakan manusia untuk beribadat kepada-Nya akan tetapi ia bukan bermakna Allah SWT memerlukan manusia. Selain itu Ibn Kathir mengambil pendapat beberapa tokoh tafsir sebagai rujukan dalam menafsirkan ayat ini. Al-Ḍaḥhāk mentafsirkan ibadat yang disertai dengan kesyirikan tidak memberi manfaat kepada pelakunya kecuali ibadat orang-orang beriman ${ }^{19}$.

Ibn Kathir juga membawakan hadis dari Imam Aḥmad yang meriwayatkan dari Abū Hurayrah RA, beliau berkata bahawa Rasulullah SAW bersabda yang bermaksud "Allah Ta'ala berfirman: Wahai anak Adam, luangkanlah waktu untuk beribadah kepada-Ku, Aku akan memenuhi hatimu dengan kekayaan dan Aku menutupi kefakiranmu. Dan jika kamu tidak melakukannya, maka $\mathrm{Aku}$ akan mengisi hatimu dengan kesengsaraan dan Aku tidak akan menutupi kefakiranmu"20.

\footnotetext{
${ }^{18}$ Ibn Kathìr, Tafsìr al-Qur 'ān al- 'Ażìm, 1:123-129.

${ }^{19}$ Ibn Kathìr, Tafsìr al-Qur'ān al- 'Ażìm, 7:396.

${ }^{20}$ Ibid.
} 
Berdasarkan huraian di atas, dapat dirumuskan bahawa manusia tidak dicipta sia-sia tetapi mempunyai tanggungjawab yang besar selaku hamba Allah SWT yang taat seterusnya mentadbir alam ini dengan baik.

\section{Al-Mīzān sebagai Konsep Keseimbangan Alam}

Alam merupakan salah satu ciptaan Allah SWT yang menakjubkan. Setiap ciptaan Allah dalam alam ini berkait rapat dengan aspek keseimbangan. Kehidupan yang berada dalam alam ini telah diberikan peranan masingmasing untuk mewujudkan keseimbangan sesama sendiri. Ini termasuklah manusia, haiwan dan juga tumbuhtumbuhan. Ketiga-tiganya mempunyai hubungan yang saling memerlukan untuk keseimbangan alam ini. Melalui hubungan inilah, Allah telah melarang berlakunya perilaku-perilaku yang menyalah gunakan alam ini seterusnya memberi kesan yang buruk kepada hidupanhidupan di alam ini.

Keseimbangan alam dalam Islam tidak dapat lari daripada konsep al-Mīzān. Konsep ini ialah satu konsep yang dianjurkan oleh Islam untuk menjaga ekosistem khasnya. Berdasarkan konsep ini, Allah telah memberikan peranan dan tanggungjawab kepada setiap makhluk untuk dilaksanakan. Jika peranan atau tanggungjawab yang diamanahkan tidak dilakukan, maka sistem alam ini akan berubah $^{21}$. Setiap perkara yang dilakukan oleh manusia perlu mengambil kira konsep al-Miżān ini. Penekanan kepada perlakuan oleh manusia ini adalah kerana manusia khalifah $^{22}$ di muka bumi.

${ }^{21}$ Noor Shakirah Mat Akhir, "Rohani Manusia dan Alam Sekitar dari Perspektif Islam”, Jurnal IKIM, 12(2). Julai/Disember 2004, 163.

22 Khalifah (خليفة) berasal daripada perkataan Arab. Khalifah merujuk kepada seorang wakil atau pengganti. Khalifah dalam Islam merujuk kepada peribadi seseorang itu yang memegang hak dalam kekuasaan untuk beliau menjalankan agama dan hukum Islam iaitu syariat Islam dalam sebuah negara Islam. Dia juga adalah merupakan wakil atau pengganti Rasulullah SAW. Majid Ali Khan, Sisi Hidup Para 
Selain itu juga, konsep al-Mīzān adalah sistem alam yang mengambil kira hubungan antara setiap unsur alam dan juga sesama makhluk khususnya peranan yang dimainkan oleh manusia selaku khalifah di alam ini. Sistem yang telah diwujudkan oleh Allah ini tidak akan terjejas sekiranya kerakusan dan sifat manusia dalam mengeksploitasi alam melalui aktiviti pembangunan yang melebihi batasnya dapat dielakkan. Ini kerana sistem inilah yang membentuk keseimbangan menerusi unsurunsur tertib, harmoni dan saling lengkap-melengkapi antara satu sama lain ${ }^{23}$.

Seterusnya, keseimbangan yang perlu ada dalam alam ini perlulah keseimbangan yang menyeluruh dan dinamik. Allah telah mewujudkan keseimbangan alam dari bermulanya penciptaan alam ini. Walaupun kewujudan isi-isi alam ini dalam bilangan yang banyak, akan tetapi alam ini berada dalam keadaan yang seimbang. Ini kerana Allah telah mewujudkan suatu ikatan yang berbentuk kebergantungan sesama makhluk untuk keseimbangan alam. Ini dapat dilihat dengan fungsi-fungsi yang dilakukan oleh makhluk ciptaan Allah seperti bintang-bintang yang tidak berlanggar dan sentiasa bergerak dalam orbit atau laluannya sendiri ${ }^{24}$. Allah juga telah menyebut berkaitan keseimbangan dalam surah alMulk ayat 3:

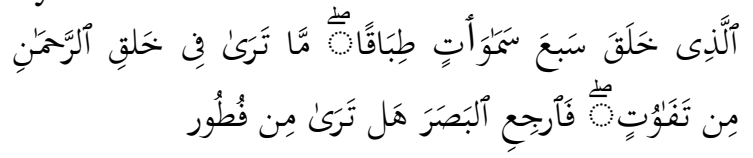

Khalifah Saleh (Jakarta: Risalah Gusti, 2000), 1. Dengan erti kata lain khalifah di sini merujuk kepada seseorang yang berperanan mengabdikan diri kepada Allah menerusi pelaksanaan hukum Allah dan melakukan amal soleh dalam bentuk yang sempurna.

${ }^{23}$ Noor Shakirah, "Rohani Manusia dan Alam Sekitar", Jurnal IKIM, 163.

${ }^{24}$ Zakaria Awang Soh, Kejadian dan Keadaan Alam Semesta (Kuala Lumpur: Berita Publishing Sdn. Bhd, 1990), 151. 
Terjemahan: Dialah yang telah mengaturkan kejadian tujuh petala langit yang berlapis-lapis, engkau tidak dapat melihat pada ciptaan Allah Yang Maha Pemurah itu sebarang keadaan yang tidak seimbang dan tidak munasabah, (jika engkau ragu-ragu) maka ulangilah pandanganmu-dapatkah engkau melihat sebarang kecacatan?

Hamka dalam mentafsirkan ayat ini telah membincangkan berkenaan dengan kedudukan bintangbintang dalam cakerawala yang mempunyai susunan dalam jarak yang teratur dan tertentu. Oleh itu, bintangbintang ini berada dalam lingkungan masing-masing tanpa mengganggu antara satu sama lain. Selain itu, beliau juga memberi contoh ciptaan Allah yang lain. Ini termasuklah matahari dan bulan. Beliau memberi gambaran bulan itu akan kelihatan penuh pada hari k- empat belas dan ia akan kelihatan sebesar matahari.

Namun berdasarkan pengetahuan dan kajian manusia, bulan itu jauh lebih kecil daripada matahari dan bumi. Ini adalah salah satu bukti terhadap ilmu Allah dalam mengatur dan menyeimbangkan sesuatu ciptaan-Nya. Oleh itu, tidak terdapat kejanggalan atau ketidak seimbangan yang dicipta oleh Allah terhadap semua makhluk ciptaan-Nya ${ }^{25}$.

Berdasarkan perbincangan Hamka dapat disimpulkan bahawa Allah telah mencipta sesuatu perkara itu dengan cukup sempurna sama ada dari fungsi atau peranannya antara satu dengan yang lain. Keseimbangan penciptaan Allah ini telah dibuktikan sama ada dari penciptaan carekawala itu sendiri mahupun ciptaan yang terdapat di muka bumi. Oleh itu, manusialah yang berperanan untuk menjaga serta mengawal keseimbangan ini khususnya

${ }^{25}$ Hamka, Tafsir al-Azhar, 10:8. 
dalam aspek alam sekitar agar tidak terjadi kemusnahan dan kebinasaan alam.

Selain itu juga, Ibn Kathīr dalam tafsirannya telah membahagikan ayat di atas kepada beberapa ayat. Beliau telah menafsirkan ayat "Yang telah menciptakan tujuh langit berlapis-lapis" dengan menjelaskan bahawa langit itu bertingkat-tingkat. Beliau juga membahagikan dua pendapat berkenaan ayat ini dan menyimpulkan bahawa pendapat yang lebih diterima ialah pendapat yang mempunyai hadis Isrā'. Seterusnya dalam ayat "Kamu sekali-kali tidak melihat pada ciptaan Rabb yang Maha Pemurah sesuatu yang tidak seimbang", Ibn Kathï berpendapat bahawa semua yang diciptakan oleh Allah SWT adalah saling bersesuaian dan saling mengimbangi antara satu dengan yang lain.

Beliau juga berpendapat bahawa penciptaan ini tidak mempunyai pertentangan, ketidakseimbangan, kekurangan, keaiban dan kerosakan. Dalam ayat "Maka lihatlah berulang-ulang, adakah kamu lihat sesuatu yang tidak seimbang?", beliau mentafsirkan dengan perlu melihat ke langit kerana tidak terdapat cacat, kekurangan, kerosakan atau ketidakseimbangan. Ibn Kathir juga telah memetik pandangan Ibn 'Abbās, Mujāhid dan beberapa ulama lain dengan mengatakan bahawa ayat "Maka lihatlah berulang-ulang, adakah kamu lihat sesuatu yang tidak seimbang" ini merujuk kepada maksud 'pecah'. Manakala al-Suddi berpendapat ayat tersebut merujuk kepada maksud 'kerosakan' ${ }^{\text {, }}$.

Konsep al-Mīzān mempunyai hubungan yang berkait rapat dengan takdir. Ini kerana takdir merujuk kepada ketentuan Allah untuk mengekalkan keseimbangan alam ini. Takdir juga berperanan menghuraikan dan mengaplikasikan takdir dalam membantu penjagaan alam sekitar. Selain itu, takdir juga mempunyai peranan yang

${ }^{26}$ Ibn Kathīr, Tafsìr al-Qur 'ān al- 'Ażìm, 8:197. 
besar untuk memberi ruang kepada manusia untuk menjaga alam ini.

\section{Takdir}

Takdir merupakan antara aspek yang perlu dititik beratkan dalam usaha seseorang melestarikan alam. Ini kerana takdir yang akan menentukan keadaan alam khususnya alam sekitar. Mempercayai takdir merupakan salah satu intipati yang terdapat dalam rukun iman. Takdir merupakan salah satu perkara yang wajib dipercayai dan diimani oleh setiap Muslim. Ini termasuklah takdir baik mahupun takdir yang buruk. Setiap perkara yang terjadi sama ada perkara yang berlaku itu baik atau pun buruk, ia telah ditentukan oleh Allah SWT.

Takdir juga secara umumnya merujuk kepada qadar. Qadar secara literalnya merujuk ukuran, ketentuan dan aturan $^{27}$. Qadar menurut Lisān al-'Arāb ialah sebahagian daripada sifat-sifat dan kekuasaan Allah dalam menentukan takdir ${ }^{28}$. Takdir (تقدير) secara bahasanya bermaksud penaksiran, penilaian atau penganggaran ${ }^{29}$. Takdir dari sudut istilah bermaksud bahawa Allah itu telah menentukan dan meletakkan sesuatu undang-undang atas sesuatu itu dengan sesuatu itu sesuai dengan ukuran dan aturannya $^{30}$.

Namun begitu, takdir dengan lebih terperinci lagi dikenali sebagai qada' dan qadar daripada Allah SWT. Imam Abū Hasan al-Ash ari dan majoriti ulama Ahl alSunnah wa al-Jamā'ah mendefinisikan qada' sebagai kehendak Allah pada azali (sedia kala) yang bergantung kepada sesuatu dan menepati dengan perkara yang diadakan. Qadar pula bermaksud sesuatu menurut yang

${ }^{27}$ Abd. Rahim Nur, Percaya kepada Taqdir: Membawa Kemajuan atau Kemunduran (Singapura: Solo Enterprises, 1981), 25.

${ }^{28}$ Ibn Manẓūr, Lisān al-Arāb, 5:74.

${ }^{29}$ Mohd Khairi et.al., Kamus al-Miftah, 515.

${ }^{30}$ M. Fadli A. Bakar, Qada dan Qadar: Asas Kesedaran, Motivasi dan Kejayaan Hidup Muslim (Kuala Lumpur: Pustaka Syuhada, 2003), 2. 
ditentukan oleh qada'nya dalam keadaan sifat, masa, kedudukan dan juga sebab ${ }^{31}$. Selain itu, qada' juga adalah mengenai hukum atau ketentuan Ilahi yang menentukan perkara yang sepatutnya berlaku terhadap makhlukmakhluk ciptaan-Nya walhal keadaan yang berlaku dari azali atau asalnya adalah kekal. Jadi secara ringkasnya qada' membawa kepada maksud hukum, ketentuan, resam, kepastian dan ketetapan.

Qadar pula adalah suatu hubung kait antara iradah atau kemahuan diri dengan sesuatu pada waktu yang tertentu. Maka hubungan seluruh keadaan dari keadaankeadaan seseorang itu yang berkaitan dengan waktu yang tertentu dan sebab yang tertentu dan ia adalah gambaran tentang qadar ${ }^{32}$. Elemen qada' dan qadar saling berkait rapat dan perbincangan berkenaan takdir harus mempunyai kedua-dua elemen ini. Qāmūs al-Munjid mentafsirkan qadar sebagai mengukur sesuatu itu dengan sesuatu $^{33}$.

Alam semesta ini juga merupakan takdir daripada Allah SWT. Ia tidak dijadikan secara sia-sia tanpa hikmah atau keuntungan kepada penghuninya. Ia merupakan takdir yang telah ditentukan oleh Allah SWT dalam mencipta alam ini. Takdir Allah adalah salah satu cebisan kecil keagungan ilmu milik Allah. Ini kerana ilmu-Nya meliputi setiap sesuatu walaupun sesuatu itu belum lagi diciptakan. Allah sudah menentukan ukuran yang cantik dan seimbang terhadap sesuatu perkara sama ada dalam bentuk dan sifatnya. Ini telah dihuraikan dalam al-Qur'an melalui ayat 49 dalam surah al-Qamar.

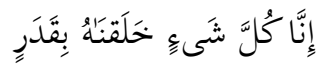

31 Abdul Hadi Awang, Beriman Kepada Qada' dan Qadar (Batu Caves: PTS Islamika, 2008), 5.

${ }^{32}$ M. Fadli, Qada dan Qadar, 1-2.

${ }^{33}$ Qamus al-Munjid (Beirut: Dār al-Masyhriq, 2005), 780. 
Terjemahan: Sesungguhnya Kami menciptakan tiap-tiap sesuatu menurut takdir (yang telah ditentukan)"

Begitu juga dengan ayat 2 dalam surah al-Furqān.

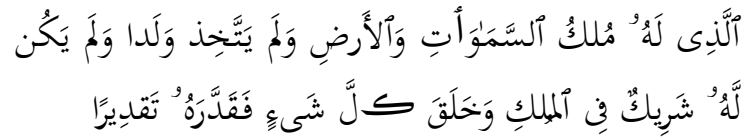

Terjemahan: Tuhan yang menguasai pemerintahan langit dan bumi, dan yang tidak mempunyai anak, serta tidak mempunyai sebarang sekutu dalam pemerintahan-Nya, dan Dialah yang menciptakan tiap-tiap sesuatu lalu menentukan keadaan makhluk-makhluk itu dengan ketentuan takdir yang sempurna.

Ayat-ayat al-Qur'an ini membuktikan Allah SWT menggariskan berkenaan dengan kadar atau peranan takdir dalam penciptaan alam ini. Begitu juga peranan manusia yang telah Allah tetapkan dalam menjaga alam sekitar ini dan sekiranya manusia itu melanggar perkara yang telah ditetapkan oleh Allah, akan wujud ketidakseimbangan seterusya membawa kemusnahan dan kebinasaan.

Yūsuf al-Qarāọāwī juga membincangkan berkenaan takdir dalam penulisannya. Beliau telah membahagikan tiga elemen dalam ruang lingkup berkaitan dengan takdir. Pertamanya ialah berkenaan dengan alam semesta. Ini termasuklah angin, udara, bintang, matahari dan sebagainya. Semua ini berfungsi atas kehendak Allah SWT dan semua ini tidak sesekali terlepas daripada pengetahuan Allah SWT. Semuanya bergerak atas ketetapan Allah $\mathrm{SWT}^{34}$.

Seterusnya ruang lingkup yang kedua ialah perkara yang terjadi kepada manusia itu sendiri. Contohnya sebab manusia itu dicipta dan untuk apa manusia itu diciptakan.

${ }^{34} \mathrm{Ibid}, 21$. 
Persoalan-persoalan seperti ini tidak mempunyai jawapan yang tepat tetapi jelas menunjukkan ia adalah ketentuan dan takdir Allah SWT. Namun begitu, takdir inilah yang memerlukan manusia itu supaya reda dengan ketentuan Allah SWT dan yakin setiap yang Allah berikan atau wujudkan adalah hikmah ${ }^{35}$.

Terakhirnya ruang lingkup yang ketiga iaitu kebebasan manusia itu dalam memilih. Contohnya seperti makan dan minum. Persoalan ini disepakati oleh ulama ia adalah dari manusia walaupun Allah telah menentukannya daripada Lawh Mahfūz lagi. Ini kerana mustahil Allah mencipta sesuatu itu tetapi Allah yang melakukannya ${ }^{36}$.

Maka, Allah telah memberi pilihan kepada manusia untuk memilih perkara yang baik ataupun yang buruk. Ini semua terletak kepada kehendak manusia untuk menentukannya. Begitu juga dengan penciptaan alam ini, Allah telah mencipta bumi ini dengan kadar dan keseimbangan yang terbaik, maka perlu untuk manusia itu menjaganya agar tidak berlaku sebarang ketidakseimbangan seterusnya merosakkannya.

\section{Ayat-ayat berkaitan Penjagaan Alam Sekitar dalam Al-Qur'an}

Pemilihan ayat-ayat ini berdasarkan istilah atau perkataan yang melarang manusia membuat kerosakan (فساد), menyuruh memakmurkan alam (استعمر) dan larangan bersikap sombong di dunia (مرحا). Kesemua ayat ini boleh dikaitkan dengan penjagaan alam sekitar. Taburan ayatayat ini seperti jadual di bawah.

Jadual 1: Senarai Taburan Ayat-Ayat berkaitan Penjagaan Alam

\begin{tabular}{|c|c|c|c|c|}
\hline \multicolumn{5}{|c|}{ Sekitar } \\
\hline Bil & Surah & Ayat & Istilah & Maksud \\
\hline 1 & $\begin{array}{l}\text { Al- } \\
\text { Baqarah }\end{array}$ & 11 & 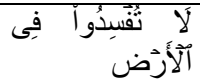 & $\begin{array}{l}\text { Janganlah kamu } \\
\text { membuat kerosakan }\end{array}$ \\
\hline
\end{tabular}

${ }^{35} \mathrm{Ibid}, 23$.

${ }^{36} \mathrm{Ibid}, 27$. 
'Imaduddin \& Noor Shakirah, "Tafsir Ayat-Ayat al-Quran berkenaan Penjagaan Alam Sekitar,” Afkār Vol. 18 Issue 1 (2016): 91-130

\begin{tabular}{|c|c|c|c|c|}
\hline & & & & di muka bumi \\
\hline 2 & $\begin{array}{l}\text { Al- } \\
\text { Baqarah }\end{array}$ & 60 & 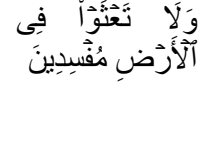 & $\begin{array}{l}\text { Janganlah kamu } \\
\text { berkeliaran di muka } \\
\text { bumi dengan } \\
\text { berbuat kerosakan. }\end{array}$ \\
\hline 3 & $\begin{array}{l}\text { Al- } \\
\text { Baqarah }\end{array}$ & 205 & 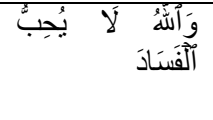 & $\begin{array}{ll}\text { Allah } & \text { tidak } \\
\text { menyukai } & \\
\text { kebinasaan } & \end{array}$ \\
\hline 4 & Al-Māidah & 64 & 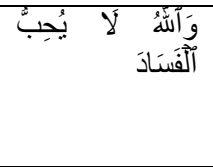 & $\begin{array}{lr}\text { Allah } & \text { tidak } \\
\text { menyukai } & \text { orang- } \\
\text { orang } & \text { yang } \\
\text { membuat kerosakan. }\end{array}$ \\
\hline 5 & Al-A'rāf & 56 & 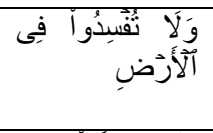 & $\begin{array}{l}\text { Janganlah kamu } \\
\text { membuat kerosakan } \\
\text { di muka bumi }\end{array}$ \\
\hline 6 & Al-A'rāf & 74 & 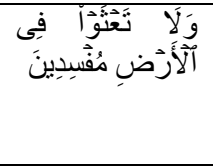 & $\begin{array}{l}\text { Janganlah } \text { kamu } \\
\text { merajalela di muka } \\
\text { bumi membuat } \\
\text { kerosakan. }\end{array}$ \\
\hline 7 & Al-A'rāf & 85 & 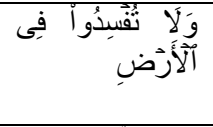 & $\begin{array}{l}\text { Janganlah kamu } \\
\text { membuat kerosakan } \\
\text { di muka bumi }\end{array}$ \\
\hline 8 & Al-A'rāf & 142 & 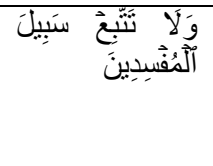 & $\begin{array}{lr}\text { Janganlah } & \text { kamu } \\
\text { mengikuti } & \text { jalan } \\
\text { orang-orang } & \text { yang } \\
\text { membuat kerosakan. }\end{array}$ \\
\hline 9 & Hūd & 61 & 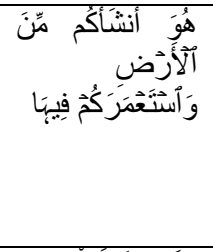 & $\begin{array}{lr}\text { Dia lah } & \text { Yang } \\
\text { menjadikan } & \text { kamu } \\
\text { dari bahan-bahan } \\
\text { bumi, } & \text { serta } \\
\text { menghendaki } & \text { kamu } \\
\text { memakmurkannya. }\end{array}$ \\
\hline 10 & Hūd & 85 & 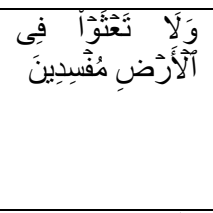 & $\begin{array}{l}\text { Janganlah kamu } \\
\text { membuat kejahatan } \\
\text { di muka bumi } \\
\text { dengan membuat } \\
\text { kerosakan. }\end{array}$ \\
\hline 11 & Al-Isrā' & 37 & 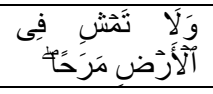 & $\begin{array}{lr}\text { Dan } & \text { janganlah } \\
\text { Engkau berjalan di }\end{array}$ \\
\hline
\end{tabular}


'Imaduddin \& Noor Shakirah, "Tafsir Ayat-Ayat al-Quran berkenaan Penjagaan Alam Sekitar," Afkār Vol. 18 Issue 1 (2016): 91-130

\begin{tabular}{|c|c|c|c|c|}
\hline & & & & $\begin{array}{l}\text { bumi dengan } \\
\text { berlagak sombong }\end{array}$ \\
\hline 12 & $\begin{array}{l}\text { Al- } \\
\text { Syu'arā', }\end{array}$ & 183 & 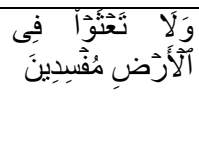 & $\begin{array}{lr}\text { Janganlah } & \text { kamu } \\
\text { merajalela di muka } \\
\text { bumi dengan } \\
\text { membuat kerosakan. }\end{array}$ \\
\hline 13 & Al-Qașaș & 77 & 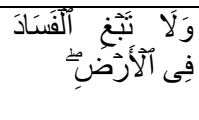 & $\begin{array}{l}\text { Janganlah kamu } \\
\text { berbuat kerosakan } \\
\text { di (muka) bumi. }\end{array}$ \\
\hline 14 & Al-Qașaș & 77 & 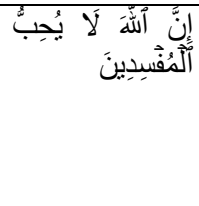 & \begin{tabular}{l}
\multicolumn{2}{l}{ Sesungguhnya } \\
Allah tidak \\
menyukai orang- \\
orang yang berbuat \\
kerosakan.
\end{tabular} \\
\hline 15 & $\begin{array}{l}\text { Al- } \\
\text { 'Ankabūt }\end{array}$ & 36 & 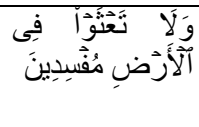 & $\begin{array}{l}\text { Dan janganlah kamu } \\
\text { melakukan } \\
\text { kerosakan di bumi }\end{array}$ \\
\hline 16 & Luqmān & 18 & 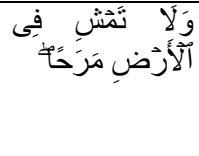 & $\begin{array}{lr}\text { Dan } & \text { janganlah } \\
\text { Engkau berjalan di } \\
\text { bumi r dengan } \\
\text { berlagak sombong }\end{array}$ \\
\hline
\end{tabular}

Berdasarkan jadual di atas, terdapat 16 ayat al-Qur'an yang dikenal pasti boleh difahami sebagai ayat-ayat penjagaan alam sekitar. Walau bagaimanapun, seperti yang disebutkan sebelum ini, ayat-ayat ini tidak menjurus secara khusus dalam menghuraikan penjagaan alam sekitar. Ia hanya boleh difahami secara tersurat sahaja. Oleh itu, untuk mencari yang tersirat, kitab Tafsir alMisbah serta beberapa tafsir utama lain akan digunakan dalam mentafsirkan ayat ini. Selain itu juga, terdapat banyak ayat-ayat yang berulang-berulang. Justeru itu, hanya beberapa ayat sahaja akan diambil sebagai sampel untuk dijadikan ayat-ayat penjagaan alam sekitar.

\section{Ayat-ayat Penjagaan Alam Sekitar dalam al-Qur'an}

Ayat-ayat yang dikenal pasti ini bukanlah ayat khusus yang menerangkan penjagaan alam sekitar. Ayat-ayat yang dipilih ini lebih bersifat umum dan tidak menyebut 
elemen alam sekitar secara khusus akan tetapi terdapat perkataan الأرض (bumi) di dalamnya. Jadi, perkataan dijadikan kunci utama untuk mendapatkan ayat-ayat ini kerana bumi mempunyai hubungan yang sinonim dengan alam sekitar. Akan tetapi daripada enam belas ayat yang dikenal pasti, hanya tiga ayat sahaja yang dipilih untuk dijadikan sampel dalam menganalisis ayat-ayat alQur'an berkaitan pemeliharaan alam sekitar. Kaedah ini bertujuan untuk meringkaskan perbincangan.

1. Surah al-Baqarah ayat 60 :

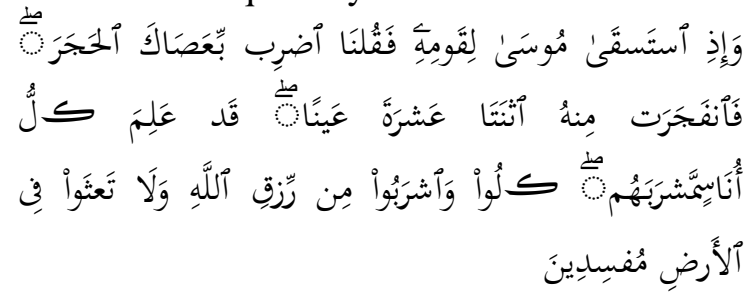

Terjemahan: Dan (ingatlah) ketika Nabi Musa memohon supaya diberi air untuk kaumnya, maka Kami berfirman: pukullah batu itu dengan tongkatmu, (dia pun memukulnya), lalu terpancutlah dari batu itu dua belas mata air, sesungguhnya tiap-tiap satu puak (di antara mereka) telah mengetahui tempat minumnya masing-masing. (Dan Kami berfirman): makanlah dan minumlah kamu dari rezeki Allah itu, dan janganlah kamu merebakkan bencana kerosakan di muka bumi.

Tafsir al-Azhar menghuraikan bahawa setiap nikmat yang diberikan kepada manusia, ia haruslah diambil sebagai salah satu cara untuk mengingati Allah SWT. Berdasarkan tafsir tersebut juga ayat di atas melarang seseorang itu mengeluh sekiranya tidak mendapat nikmat 
yang dihajati dan lupa diri serta sombong jika mendapat sesuatu nikmat daripada Allah SWT $^{37}$.

Menurut Sayyid Quṭb dalam Tafsir Fì Zilāl alQur'ān pula, perkara yang terjadi kepada Bani Israel ini merupakan salah satu cara untuk Allah mengeluarkan mereka daripada kehinaan kepada kemuliaan. Tetapi kebebasan itu mempunyai harga yang perlu dibayar oleh mereka. Kemuliaan ini haruslah diterjemahkan dengan perlaksanaan amanah yang dipertanggungjawabkan di atas bahu mereka sepeti tidak melakukan kerosakan ke atas alam ini ${ }^{38}$.

Menurut Quraish Shihab dalam Tafsir al-Misbah dalam mentafsirkan ayat 60 surah al-Baqarah di atas, beliau menyentuh sedikit ayat sebelumnya iaitu ayat 59 . Dalam ayat 59, Allah telah menggariskan nikmat-nikmat yang diberikan ketika Bani Israel memasuki kota yang subur dan dipenuhi dengan pelbagai hasil-hasil bumi. Manakala dalam ayat 60 , penekanan telah diberikan oleh Allah SWT berkenaan dengan nikmat air yang telah diberikan kepada suku-suku Bani Israel. Pemberian nikmat air ini bersifat umum dan boleh terjadi pada manamana tempat dan bila-bila waktu sahaja.

Allah telah mengabulkan permintaan Nabi Musa dengan cepat dan tanpa penantian seperti yang boleh difahami melalui penggunaan huruf ف (fa') yang bererti maka dan bukannya $ث$ (kemudian). Ini berdasarkan firman Allah فقلنا اضربوه ببغضها yang bermaksud "maka Kami berfirman: pukullah dengan tongkatmu batu". Didahulukan kata tongkat pada pangkal ayat ini adalah untuk mengisyaratkan bahawa tongkat tersebut memiliki keistimewaan sebagai mukjizat Nabi Mūsā. Namun ada pandangan bahawa doa Nabi Musa itu diperkenankan Allah tetapi bukan serta merta namun kedua-dua

${ }^{37}$ Hamka, Tafsīr al-Azhar, 1:200.

${ }^{38}$ Sayyid Quṭb, Fì Zilāl al-Qur'ān, (Kaherah: Dar al-Shurūq, 2003), $1: 74$. 
pandangan tetap memberi maksud perlu ada usaha. Dan dalam kisah ini usaha Nabi Musa itu adalah memukul batu dengan tongkatnya ${ }^{39}$.

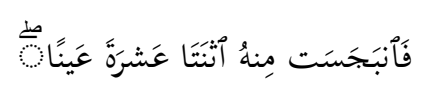

Terjemahan: Maka terpancarlah daripadanya dua belas mata air".

\section{Al-`Arāf: 160}

Kedua-dua istilah ini tidak bertentangan kerana ia berbicara tentang awal kemunculan atau terpancarnya mata air dan setelah beberapa lama dari pancaran pertama. Seterusnya "dua belas mata air" merujuk kepada dua belas suku atau kelompok Bani Israel yang terdiri daripada keturunan Nabi Yàqūb AS. Wujudnya mata air untuk setiap suku merupakan nikmat yang besar kerana setiap suku mempunyai hak masing-masing. Ini akan mengelakkan pergeseran dan pertengkaran sesama sendiri seterusnya dapat mengukuhkan dan menjaga hubungan antara mereka.

Di akhir ayat ini Allah mengingatkan untuk tidak melakukan kerosakan di bumi ini. Tafsir al-Misbah menafsirkan ayat "dan janganlah kamu berkeliaran di muka bumi ini dengan berbuat kerosakan" dengan merujuk kepada usaha untuk menjaga kelestarian atau kesejahteraan alam, menjaga kebersihan persekitaran alam ini, larangan menggunakan air yang berlebihan atau membazir ${ }^{40}$.

Pentafsiran ayat 60 surah al-Baqarah ini menurut Tafsìr al-Marāghì pula, larangan untuk tidak menyebarkan kerosakan di atas muka bumi dilakukan selepas Bani Israel diberikan kenikmatan yang berupa makanan dan minuman yang lazat. Larangan ini kerana untuk mengingatkan mereka bahawa supaya tidak

\footnotetext{
${ }^{39}$ M. Quraish Shihab, Tafsir al-Misbah, (Jakarta: Lentera Hati, 2009), 1: 249-252.

${ }^{40}$ Ibid, 249-252.
} 
membalas nikmat yang diberikan dengan sikap kufur. Selain itu juga, ia merupakan sebagai langkah pencegahan agar tidak menjadi ikutan bangsa lain untuk merosakkan alam ini seterusnya mengundang kemurkaan Allah SWT. Larangan untuk tidak melakukan kerosakan ini juga bertujuan untuk mengikis dasar dan amalan syirik yang telah berakar umbi dalam hati Bani Israel dan membersihkan kekotoran dan kehinaan yang membentuk jiwa supaya menyembah Allah SWT semata-mata ${ }^{41}$.

Manakala menurut Tafsir al-Misbah, walaupun secara panjang lebarnya tafsir ini menerangkan berkenaan Nabi Musa a.s dan kaumnya dan kemukjizatan tongkatnya, akan tetapi terdapat cara-cara penjagaan alam sekitar yang boleh diambil melalui pentafsiran ayat larangan merosakkan muka bumi ini. M. Quraish Shihab menggariskan beberapa langkah dan salah satu langkah yang penting dalam menjaga alam sekitar ialah dengan menjaga kebersihan alam sekitar. Kebersihan merupakan salah satu elemen yang perlu ada kepada individu, keluarga dan juga masyarakat. Ini kerana persekitaran yang bersih membolehkan ibadat dilakukan kepada Allah SWT dalam keadaan yang tenang.

Seterusnya, huraian Tafsir al-Misbah juga berkenaan dengan Nabi Mūsā dan Bani Israel. Penekanan telah diberikan kepada kepentingan air yang diberikan oleh Allah kepada Bani Israel melalui mukjizat Nabi Mūsā AS. Tafsir al-Misbah menghuraikan bahawa walaupun doa Nabi Mūsā AS dimakbulkan dalam masa yang singkat, itu tidak bermakna bahawa berdoa kepada Allah SWT hanya sekadar memohon. Ia juga perlu disertai dengan usaha. Begitu juga dalam menjaga alam sekitar ini, seseorang yang cintakan alam ini bukan hanya perlu berdoa agar Allah SWT menjaga alam ini tetapi dia juga perlu

${ }^{41}$ Aḥmad Musțāfā Al-Marāghī, Tafsīr al-Marāghī, jil. 1 (t.tp: Dar alFikr, t.t), 125-127. 
berusaha melalui tenaganya untuk memastikan alam ini terpelihara.

Seterusnya berkenaan dengan peringatan Allah untuk tidak melakukan kerosakan di bumi ini, Tafsir al-Misbah telah menghuraikan bahawa kelestarian dan kebersihan alam sekitar ini juga perlu dijaga. Kesan daripada usaha penjagaan ini seterusnya mampu untuk membendung pencemaran yang berlaku kepada alam sekitar. Ini kerana alam sekitar yang bersih mampu menjauhkan manusia daripada kemudaratan seperti penyakit dan sebagainya. Contohnya penyakit denggi yang diberi perhatian serius di kawasan bandar Jawi, Nibong Tebal untuk menanganinya. Perhatian serius ini diberikan kerana daerah itu merekodkan 64 kes pada tahun 2013 berbanding 60 kes pada tahun sebelum itu.

Selain itu, penyakit ini juga merupakan antara salah satu penyakit berbahaya yang wujud hasil daripada persekitaran yang tidak bersih ${ }^{42}$. Kes denggi yang dilaporkan di Malaysia merupakan antara kes yang tertinggi dengan jumlah kes yang mencecah 100,000 kes dan dijangka akan meningkat sehingga hujung tahun $2014^{43}$. Ini terjadi disebabkan sifat manusia itu yang tidak bersyukur dengan nikmat yang diberikan seterusnya tidak menjaga alam sekitar ini dengan sempurna dan baik. Jika dilihat daripada pandangan yang berbeza, penyakit seperti ini adalah merupakan amaran Allah SWT kepada hambahamba-Nya agar sentiasa menjalankan amanah sebagai khalifah di bumi ini khususnya dalam menjaga alam sekitar agar sentiasa bersih.

Tambahan pula ia juga bersesuaian dengan ajaran agama Islam itu sendiri dan juga Allah SWT yang suka

\footnotetext{
${ }^{42}$ Zainulfaqar Yaacob (2014). “ADUN Pandang Serius Wabak Denggi” dalam Buletin Mutiara, edisi 16-31 Januari, h. 27.

43 M Hifzuddin Ikhsan (2014). "Kes Denggi Boleh Catat Angka Tertinggi Negara" dalam Berita Harian. Jumaat 8 Ogos 2014, h. 18.
} 
kepada kebersihan. Ini seperti yang dirakamkan oleh alQur'an dalam surah al-Baqarah ayat 222:

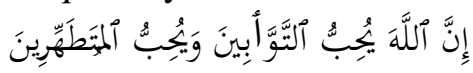

Terjemahan: Sesungguhnya Allah mengasihi orang-orang yang banyak bertaubat, dan mengasihi orang-orang yang sentiasa mensucikan diri.

Rumusannya dalam usaha untuk melestarikan alam ini, sifat syukur perlu dititik beratkan untuk melahirkan seseorang yang menghargai alam sekelilingnya khususnya menjaga kebersihan alam sekitar yang banyak memberi manfaat seperti yang disarankan dalam Tafsir al-Misbah.

2. Surah al-A'raf ayat 74 .

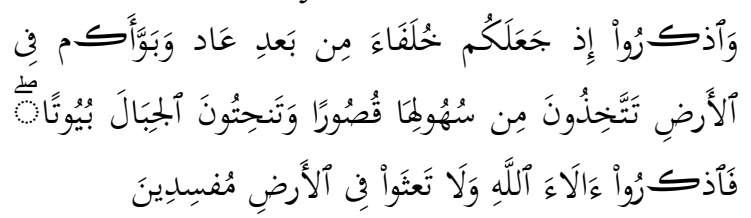

Terjemahan: Dan kenanglah ketika Allah menjadikan kamu khalifah-khalifah sesudah kaum 'A $\bar{d}$, dan di tempatkannya kamu di bumi, (dengan diberi kemudahan) untuk kamu mendirikan istana-istana di tanahnya yang rata, dan kamu memahat gunung-ganangnya untuk dijadikan rumah. Maka kenangkanlah nikmatnikmat Allah itu dan janganlah kamu bermaharajalela melakukan kerosakan di muka bumi.

Berkaitan ayat ini, Tafsīr al-Marāghì menafsirkan bahawa kaum Thamūd telah dikurniakan oleh Allah dengan peradaban yang tinggi dan kemakmuran masyarakat. Allah telah mengurniakan kaum ini ilham dan kepakaran melalui bidang pertukangan khususnya dalam pembinaan rumah yang dijadikan tempat tinggal mereka. 
Oleh itu Allah telah menyeru agar mereka mengingati nikmat Allah SWT melalui rasa syukur kepada-Nya. Sifat syukur ini boleh diterjemahkan dengan menyembah Allah semata-mata dan tidak menggunakan nikmat-nikmat yang diberikan dengan sikap kufur dan ingkar. Ini termasuklah melakukan perkara-perkara yang tidak diredai Allah khususnya dengan melakukan kerosakan ke atas muka bumi ini ${ }^{44}$.

Tafsir al-Misbah juga menafsirkan ayat kisah Nabi Șālịh dan kaumnya. Menurut tafsir ini, kaum Thamūd merupakan kaum yang diberikan keistimewaan oleh Allah SWT dalam seni pertukangan. Hasil daripada kelebihan inilah mereka berupaya untuk membina kediaman mereka di lereng-lereng bukit. Selain itu, mereka juga merupakan salah satu kaum yang mempunyai peradaban yang tinggi selepas kaum 'Ād. Ini kerana mereka mengambil pengajaran daripada keburukan kaum 'Ād yang telah diazab oleh Allah SWT. Kaum Thamūd merupakan kaum yang beriman kepada Allah pada mulanya, namun lama kelamaan mereka kembali menjadi seperti kaum 'Ād yang mempersekutukan Allah SWT.

Oleh itu, Allah telah mengutuskan Nabi Șālịh untuk mengajak mereka kembali kepada Allah SWT dan tidak melakukan kerosakan di muka bumi ini. Nabi Șālị mengajak kaumnya untuk menghayati dan menghargai setiap nikmat yang Allah berikan termasuklah kepakaran yang dikurniakan dalam pembinaan kediaman mereka. Akan tetapi, mereka sama sekali tidak beribadat kepada Allah apatah lagi untuk mensyukuri nikmat Allah SWT. Mereka telah mencari alasan untuk melihat bukti kebesaran Allah agar dapat kembali menyembah Allah.

Hasilnya, Allah menjadikan seekor unta melalui mukjizat yang diberikan kepada Nabi Șālị̣ AS sebagai membuktikan kekuasaan dan keupayaan Allah dan

${ }^{44}$ Al-Marāghī, Tafsīr al-Marāghì, 3:1:199. Lihat juga Hamka, Tafsìr al-Azhar, 4: 2424. 
disamping itu juga untuk memberi kesedaran kepada kaum Thamūd agar kembali beribadah kepada Allah SWT. Akan tetapi, mereka ingkar dengan perintah Allah SWT dengan membunuh unta tadi. Hasilnya, Allah telah menurunkan azab seksa kepada mereka seterusnya mereka dihapuskan daripada muka bumi ini ${ }^{45}$. Menurut Tafsìr Fì Zilāl al-Qur'ān pula, terdapat beberapa orang daripada golongan kaum ini yang beriman kepada Allah SWT namun ramai yang menolak dakwah Nabi Shu'ayb a.s. Antaranya termasuklah golongan pembesar dan ketuaketua kaum kerana bagi mereka menerima dakwah itu akan melucutkan kekuasaan mereka dan mengembalikan mereka kepada kekuasaan Allah. Ini secara tidak langsung akan menghilangkan keistimewaan mereka sebagai ketua. Anggapan ini menunjukkan sifat bongkak mereka ${ }^{46}$.

Pengajaran yang boleh diambil daripada kisah ini untuk dijadikan panduan dalam penjagaan alam sekitar ialah seseorang itu harus menghayati nikmat-nikmat yang diberikan oleh Allah SWT. Contohnya nikmat gunungganang yang menjadi pasak kepada bumi agar tidak berlaku bencana alam contohnya seperti tanah runtuh. Gunung-ganang ini seharusnya dijaga sebaik-baiknya dan bukannya diteroka secara melampau untuk kegunaan manusia. Begitu jugalah bencana tanah runtuh yang sering berlaku di Malaysia. Terdapat pelbagai langkah yang diambil oleh kerajaan untuk menangani kejadian tanah runtuh di Malaysia, namun bencana ini kerap juga berlaku.

Menurut perbincangan dalam artikel ditulis oleh Rosmidzatul Azila, antara langkah yang mesti dititik beratkan dalam mencegah bencana ini ialah perlunya kepada penelitian projek pembangunan. Ini kerana terdapat banyak pembangunan yang dibangunkan sekarang ini tidak dikaji secara lebih mendalam. Kebanyakan pembangunan yang dilakukan sekarang ini

\footnotetext{
${ }^{45}$ M. Quraish Shihab, Tafsir al-Misbah, vol. 4, 180-181.

${ }^{46}$ Quṭb, Fì Zilāl al-Qur'ān, jil. 3, 1313.
} 
melibatkan kawasan cerun-cerun bukit dan ia memerlukan kajian dan semakan semula secara sistematik agar kejadian tanah runtuh ini tidak berulang.

Menurutnya lagi, pembangunan yang berasaskan kepada keuntungan tanpa mengambil kira keselamatan orang lain hanya akan menjadi sia-sia dan membawa padah. Selain itu, beliau juga menggariskan pihak pemaju perumahan antara yang bertanggungjawab dalam melakukan pembangunan ini dan pihak ini perlu diberi amaran oleh pihak yang berwajib. Ini kerana pembangunan ini perlu mengambil kira aspek keselamatan dan manfaat kepada masyarakat. Rosmidzatul Azila juga menyenaraikan antara kejadian tanah dan cerun runtuh yang berlaku di Malaysia adalah berpunca daripada kawasan tanah yang tidak stabil oleh kerana pembangunan yang tidak dirancang.

Oleh itu, pembangunan di tepi cerun atau lereng bukit haruslah dielakkan agar kejadian tanah runtuh ini tidak lagi berlaku ${ }^{47}$. Namun begitu, berdasarkan huraian di atas, jelas menunjukkan antara penyebab utama kejadian ini berlaku adalah kerana sifat manusia itu sendiri yang berpaksikan kepada keuntungan semata-mata tanpa mengambil kira peranan yang diletakkan oleh Allah kepada kewujudan gunung-ganang dan bukit bukau itu sendiri.

Tambahan dalam al-Qur'an sendiri Allah telah menjelaskan tentang fungsi gunung-ganang dalam mewujudkan kestabilan alam ini. Ini berdasarkan ayat 31 dalam surah al-Anbiyā'.

${ }^{47}$ Rosmidzatul Azila Mat Yamin, Teliti Projek Pembangunan Elak Kejadian Tanah Runtuh, Institut Kefahaman Islam Malaysia. http: //www.ikim.gov.my/index.php/ms/ artikel/8025-teliti-projekpembangunan-elak-kejadian-tanah-runtuh, diakses 11 September 2014. 


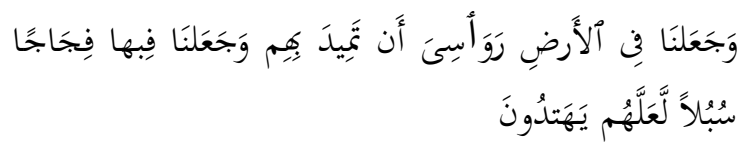

Terjemahan: Dan Kami telah menjadikan di bumi gunung-ganang yang menetapnya, supaya bumi itu tidak menggegar mereka dan Kami jadikan padanya celah-celah sebagai jalan-jalan lalu-lalang, supaya mereka dapat sampai kepada mencapai keperluan rohani dan jasmani.

Ayat di atas jelas menunjukkan bahawa kepentingan gunung-ganang dalam mewujudkan kestabilan alam ini. Bukan sahaja gunung ganang malah bukit bukau juga berperanan untuk menjadi pasak kepada bumi ini. Jadi seharusnya manusia yang telah diberikan akal fikiran mampu untuk berfikir secara waras dalam menjaga alam ini dan perlu meneliti dan berpandangan jauh sebelum melakukan sesuatu perkara sesuai dengan kelebihan akal yang dikurniakan.

Rumusannya dalam Tafsir al-Misbah, ayat di atas membincangkan berkenaan dengan kisah Nabi Soleh a.s dengan kaumnya. Dalam usaha untuk menjaga alam sekitar, seseorang itu perlu menghargai pemberian Allah SWT melalui nikmat-nikmat kurniaan-Nya. Penghargaan yang boleh dilakukan oleh seseorang itu haruslah diterjemahkan melalui perbuatannya dalam menguruskan alam ini dengan sebaiknya. Setiap kepakaran yang dikurniakan oleh Allah kepadanya haruslah digunakan dengan baik dan betul. Contohnya jika masyarakat itu mempunyai kepakaran dalam bidang menjaga alam sekitar, seharusnya mereka bijak menggunakan kepakarannya itu untuk membantu menguruskan alam ini dengan baik seterusnya mampu memberi manfaat kepada orang lain.

Ini boleh dilihat melalui program yang dianjurkan oleh Pertubuhan Pelindung Khazanah Alam Malaysia 
(PEKA) dengan kerjasama Pejabat Parlimen Bera. Dalam program ini, seramai 600 orang sukarelawan telah terlibat dalam penanaman hutan di Hutan Simpan Chini, Felda Kumai. Selain itu juga, sebanyak hampir 5,000 anak pokok hutan ditanam dan ia bertujuan untuk menghijaukan kembali kawasan seluas 28 hektar yang telah dimusnahkan oleh peneroka haram. Usaha untuk melestarikan alam sekitar ini juga dilakukan secara besarbesaran bagi menyuntik kesedaran masyarakat terhadap kepentingan menjaga khazanah bumi ini.

Menurut Menteri Pertanian dan Industri Asas Tani, selain menanam semula pokok, pihaknya mahu mendidik masyarakat supaya menjaga alam sekitar dengan mengurangkan pembuangan bahan plastik, penggunaan racun dan perbuatan yang merosakkan alam sekitar ${ }^{48}$. Program seperti ini secara tidak langsung melahirkan sifat syukur dalam diri seseorang itu dengan tidak melakukan kerosakan pada alam ini sebaliknya menjaganya. Selain itu, melalui program ini juga akan melahirkan kesedaran masyarakat awam terhadap kepentingan alam sekitar.

3. Surah al-Isrā' ayat 37

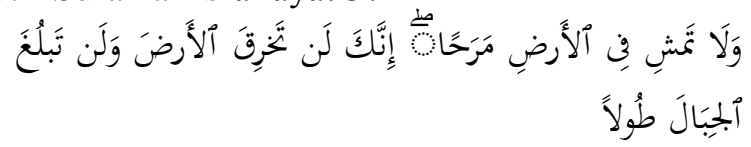

Terjemahan: Dan janganlah engkau berjalan di bumi dengan berlagak sombong, kerana sesungguhnya engkau tidak akan dapat menembusi bumi, dan engkau tidak akan dapat menyamai setinggi gunung-ganang.

Menurut huraian Tafsir al-Misbah berkenaan dengan ayat di atas, tafsir ini menghuraikan bahawa Allah melarang seseorang itu bersifat bongkak dan angkuh

\footnotetext{
${ }^{48}$ Luqman Hakim Ab, Rahim \& Ahmad Sherman Shamsuri, "Hijaukan Semula Kawasan Gondol” dalam Kosmo, edisi 19 Mei 2014, 2.
} 
dalam kehidupannya. Sifat bongkak dan angkuh ini tidak memberi sebarang faedah kepada seseorang itu kerana ini akan mengundang kemurkaan Allah SWT. Ini kerana manusia itu diciptakan dalam keadaan lemah. Walaupun seseorang itu berusaha keras untuk mendapatkan sesuatu sehinggakan kedudukannya tinggi di mata manusia, dia tidak mampu meraih kedudukan yang tinggi di sisi Allah jika mempunyai sifat sombong dan angkuh dalam dirinya.

M. Quraish Shihab memetik pandangan al-Ṭabāțabā'i dalam memahami ayat 37 yang berpendapat ayat ini hanyalah kiasan. Menurutnya, kiasan ini ditujukan kepada manusia yang menunjukkan kekuasaan ${ }^{49}$ dan kekuatan pada hakikatnya berada dalam ilusi kerana terdapat yang lebih berkuasa dan tinggi darjatnya daripada mereka walaupun mereka menghentak kaki di bumi dengan sombong dan angkuh. Oleh itu, manusia seharusnya mengakui bahawa mereka hanyalah hamba yang hina dina.

Selain itu, tidak terdapat sesuatu pun yang direbut oleh manusia seperti kerajaan, kekuasaan, kemuliaan, harta benda dan sebagainya bernilai di sisi Allah SWT dan tidak bersifat hakiki. Itu semua diciptakan dan dikurniakan Allah sebagai pinjaman kepada manusia agar digunakan untuk memakmurkan bumi dan sebagai ketetapan Allah.

49

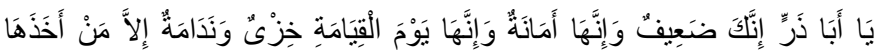

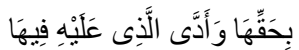

Maksudnya: Wahai Abu Dzarr, sesungguhnya engkau adalah orang yang lemah. Dan kekuasaan itu adalah amanah, dan kekuasaan tersebut pada hari kiamat menjadi kehinaan dan penyesalan, kecuali bagi orang yang mendapatkan kekuasaan tersebut dengan haknya dan melaksanakan kewajipannya pada kekuasaannya itu. Muslim, Abi Ḥusayn Muslim al-Hajjāj alQushayrī al-Naysābūi, Șahịh Muslim, Kitab al-Imārah. Hadis No. 1825 (Riyadh: Dār al-Ṭayyibah li al-Nushr wa al-Tawzi`', 2006), 885 . 
Ini boleh dikaitkan firman Allah dalam surah al-Baqarah ayat $36^{50}$ :

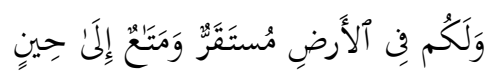

Terjemahan: Dan bagi kamu semua disediakan tempat kediaman di bumi, serta mendapat kesenangan hingga ke suatu masa (mati).

Jadi segala kenikmatan dunia ini hanyalah sementara dan sebagai tempat meraih amalan untuk dijadikan bekalan dan hujah ketika di soal Allah SWT di akhirat nanti. Begitu juga dalam penjagaan alam sekitar, walaupun alam sekitar ini tidak kekal, tetapi amanah yang diberikan Allah SWT untuk manusia menjaga dan memakmurkannya tidak boleh dipandang remeh kerana setiap perbuatan manusia ke atas alam ini akan dihisab oleh Allah. Oleh itu sifat sombong dan angkuh ini haruslah dikikis agar seseorang itu mempunyai sifat kasih dan sayang terhadap alam ini.

Ini diakui oleh Tafsìr al-Marāghì dalam menafsirkan ayat ini (Surah al-A'rāf ayat 36). Menurut tafsir ini seseorang itu hendaklah sentiasa bersikap tawaduk dan tidak takabbur kerana manusia hanyalah makhluk yang lemah dan tidak perlu untuk mereka merasakan bahawa mereka makhluk yang kuat dan serba boleh. Tambahan pula ayat ini merupakan teguran dan larangan kepada manusia yang mempunyai sifat takabbur dan tinggi diri ${ }^{51}$.

Seterusnya berdasarkan huraian Tafsir al-Misbah, manusia tidak sepatutnya mempunyai sifat angkuh dan sombong kerana mereka hanya diciptakan oleh Allah dengan sifat lemah dan hina. Manusia tidak mampu memenuhi setiap apa yang dihajatinya kerana kebolehannya terhad dan memerlukan bantuan daripada Allah SWT. Selain itu juga, setiap perkara yang

\footnotetext{
${ }^{50}$ M. Quraish Shihab, Tafsir al-Misbah, 7:89-90.

${ }^{51}$ Al-Marāghi, Tafsìr al-Marāghì, jil. 5, 46-47.
} 
dikejarkan oleh manusia dalam dunia hanyalah bersifat sementara dan sebagai pinjaman dalam menambah amalan pahala untuk hari akhirat nanti. Begitu jugalah dalam usaha untuk menjaga alam sekitar, seseorang itu haruslah meletakkan niat untuk beribadat semata-semata kerana Allah agar segala usaha kebaikannya mendapat pengiktirafan daripada Allah dan diganjari pahala yang berlipat ganda.

Namun begitu, jika melihatkan kepada situasi isu-isu alam sekitar yang berlaku di Malaysia, salah satu isu yang menunjukkan kesombongan dan sifat takabbur manusia itu ialah isu pembalakan haram. Isu ini menjadi salah satu masalah yang besar kepada kerajaan dalam usaha untuk mengekalkan keharmonian dan kemakmuran alam ini. Para pembalak haram ini menunjukkan sifat bongkak mereka dengan melakukan aktiviti mereka walaupun hukuman yang dikenakan berupa penjara dan denda.

Akan tetapi hukuman-hukuman ini tidak menjejaskan niat mereka untuk membalak dengan lebih rakus sumber mentah alam ini. Ini menyebabkan kerajaan mengambil langkah lebih agresif menguatkuasakan undang-undang dengan lebih tegas terhadap para pembalak haram ini. Pindaan undang-undang telah dibuat iaitu denda atau penalti sebanyak RM1 juta dan hukuman penjara mandatori selama 5 tahun akan dikenakan kepada pesalahpesalah pembalakan haram sekiranya mereka disabitkan kesalahan. Langkah pindaan undang-undang ini juga selaras dengan usaha kerajaan untuk mencapai empat juta hektar blok hutan di bawah Pelan Tindakan Harimau Nasional yang bermula pada tahun 2008 sehingga tahun 2020.

Selain itu, objektif tindakan ini juga bertujuan menggandakan populasi Harimau Malaya daripada apa yang dipercayai pada masa sekarang berjumlah 500 ekor dan dijangka bertambah kepada 1,000 ekor pada tahun 
2020 nanti $^{52}$. Selain itu, pada bulan Disember 2014, SPRM telah mencadangkan supaya pesalah pembalakan haram ini dikenakan hukuman sebatan bagi membolehkan kegiatan ini dibanteras habis-habisan. Langkah ini amat perlu bagi memastikan hukuman yang dikenakan lebih setimpal dengan kesalahan yang dilakukan selain mempunyai eleman pencegahan atau 'element of deterrent' agar mampu memberi pengajaran kepada pesalah dan masyarakat keseluruhannya ${ }^{53}$.

Isu pembalakan haram ini jelas membuktikan sifat sombong manusia itu yang tidak memikirkan keadaan orang lain malahan juga kepada makhluk-makhluk ciptaan Allah khususnya haiwan-haiwan yang menghuni di kawasan hutan terbabit.

\section{Kesimpulan}

Alam sekitar merupakan kurniaan dan amanah kepada umat manusia agar dipelihara supaya keseimbangan terjaga. Al-Qur'an sebagai sumber rujukan mutlak kepada manusia telah menggariskan langkah-langkah melalui ayat-ayatnya untuk membimbing seseorang itu memelihara alam ini dari berlakunya kerosakan dan kemusnahan.

Berdasarkan ayat 37 dalam surah al-Isrā', langkah pertama untuk menjaga alam sekitar seseorang itu tidak boleh mempunyai sifat sombong dan bongkak. Ini boleh diluaskan kepada larangan sifat-sifat madhmūmah yang lain dalam konteks interaksi manusia dengan alam sekitar. Seterusnya, berdasarkan ayat 74 surah al-A'rāf, langkah yang kedua ialah menerapkan konsep bersyukur dengan

52 Bernama, Tindakan Lebih Tegas Kepada Pembalakan Haram, Borneo Post Online, http://www.theborneopost.com/2011/03/22/tindakan-lebih-tegas-keatas-pembalakan-haram/ Diakses 4 November 2014.

${ }^{53}$ Sheila Rani Chandrasekaran, Sebat Pembalak Haram-SPRM, Utusan Online, http://www.utusan.com.my/berita/nasional/sebat-pembalakharam-8211-sprm-1.18959, diakses 4 September 2014. 
nikmat yang Allah kurniakan melalui alam ini. Ini dapat diluaskan kepada gesaan-gesaan dalam menerapkan sifatsifat mahmüdah dalam interaksi manusia dengan alam sekitar. Kemudiannya, berdasarkan ayat 37 dalam surah al-Baqarah, langkah yang terakhir merujuk kepada gesaan berkongsi nikmat alam ini sesama manusia dan larangan mengambil hak orang lain.

Namun, segala usaha untuk memelihara dan melestarikan alam sekitar ini, bertitik tolak daripada sifat mahmūdah dalam diri seseorang itu antaranya sifat syukur, tidak sombong dan tidak lupa diri dengan kurniaan Allah SWT. Jadi, sebagai sebuah negara yang mempunyai ramai penduduk yang beragama Islam dan berpandukan kepada al-Qur'an sebagai sumber rujukan dalam kehidupan, Malaysia seharusnya mampu menangani isu-isu alam sekitar dan dapat mengurangkan kemusnahan alam ini dengan lebih berkesan.

Di samping perlunya penekanan kepada pembaikan sahsiah dan nilai-nilai kerohanian, penekanan kepada aspek fizikal juga perlu diambil kira seperti mengurangkan pencemaran melalui pelaksanaan kitar semula bahan terbuang, penguatkuasaan undang-undang yang lebih ketat kepada pemain industri yang mencemarkan alam dan juga menaikkan kadar kompaun kepada pesalah alam sekitar.

\section{Rujukan}

Abd. Rahim Nur. Percaya kepada Taqdir: Membawa Kemajuan atau Kemunduran. Singapura: Solo Enterprises, 1981.

Abdul Hadi Awang. Beriman Kepada Qada' dan Qadar. Batu Caves: PTS Islamika, 2008.

Bernama. Tindakan Lebih Tegas kepada Pembalakan Haram, Borneo Post Online. http://www.theborneopost.com /2011/03/22/tindakanlebih-tegas-ke-atas-pembalakan-haram/ 
HAMKA, Abdul Malik Abdul Karim. Tafsìr al-Azhar, jil. 1 dan 4. Singapura: Pustaka Nasional Pte Ltd, 2007.

Hong, Lum Chee. Janda Baik Kena Ceroboh, Berita Harian, 8 Ogos 2014.

Ibn Kathīr, al-Ḥāfiz Abī al-Fidā' Ismā'‘ìl. Tafsìr al-Qur 'ān al-'Azìim, jil. 10. Beirut: Dār al-Kutub al-'Ilmiyyah, 1998.

Ibn Manzūir. Lisān al- 'Arāb. Beirut: Dār al-Dar, t.t.

Ishak Jaino,

Pemanasan

Global,

http://dspace.unimap.edu.my/dspace/bitstream

/123456789/7862/1/Pemanasan\%20global.pdf.

Izzi Dien, Mawil. The Environmental Dimensions of Islam. Cambridge: The Lutterworth Press, 2000.

Luqman Hakim Ab, Rahim \& Ahmad Sherman Shamsuri. "Hijaukan Semula Kawasan Gondol", Kosmo, 19 Mei 2014.

M Hifzuddin Ikhsan. "Kes Denggi Boleh Catat Angka Tertinggi Negara", Berita Harian, 8 Ogos 2014.

M. Fadli A. Bakar. Qada dan Qadar: Asas Kesedaran, Motivasi dan Kejayaan Hidup Muslim. Kuala Lumpur: Pustaka Syuhada, 2003.

M. Quraish Shihab. Tafsir al-Misbah. Jakarta: Lentera Hati, 2009.

Majid Ali Khan. Sisi Hidup Para Khalifah Saleh. Jakarta: Risalah Gusti, 2000.

Majlis al-A`la lì al-Shū'ūn al-Islāmiyyah. Tafsìr alMuntakhab fï Tafsìr al-Qur'ān al-Karim. Mesir: Mū'assasat al-Ahrām, 1985.

Al-Marāghi, Aḥmad Musțāfā. Tafsīr al-Marāghī, jil. 1, 3 dan 5. t.tp: Dār al-Fikr, t.t.

Mohd Khairi Zainuddin et.al. Kamus al-Miftah. Seremban: Al-Azhar Media, 2007.

Mohd Zuhdi Marzuki \& Amer Saifude Ghazali. Etika Alam Sekitar: Daripada Perspektif Islam, Timur dan Barat. Bentong: PTS Publications, 2002. 
Muslim, Abì Ḥusayn Muslim al-Hajjāj al-Qushayrī alNaysābūrí. Șahịh Muslim. Riyadh: Dār al-Ṭayyibah li al-Nushr wa al-Tawzì, 2006.

Muẓid, Yūnus Ibrāhīm Aḥmad. Al-Bī'ah fì al-Islām. t.tp: Dār al-Hamíd, 2009.

Noor Shakirah Mat Akhir, Rohani Manusia dan Alam Sekitar dari Perspektif Islam, Jurnal IKIM, 12(2). Julai/Disember (2004)

Norhibah Hasan Zawawi. Konsep Islam terhadap Pemuliharaan Alam Sekitar. Jabatan Perdana Menteri: Jabatan Kemajuan Islam Malaysia, 1999.

Qāmūs al-Munjid. Beirut: Dār al-Mashrīq, 2005.

Al-Qurțubi, Abì 'Abdullah Muhammad bin Ahmad bin Abi Bakr. Al-Jāmi' li al-Ahkam al-Qur'ān al-Karìm. Beirut: Mū'assasah al-Risālah, 2006.

Quṭb, Sayyid. Fì Zilāal al-Qur 'ān. Kaherah: Dār al-Shurūq, 2003.

Rosmidzatul Azila Mat Yamin, Teliti Projek Pembangunan Elak Kejadian Tanah Runtuh, Institut Kefahaman Islam Malaysia. http://www.ikim.gov.my/index.php/ms/artikel/8025teliti-projek-pembangunan-elak-kejadian-tanah-runtuh.

Steel, Miranda. New Oxford Dictionary, terj. Zubaidah Abdul Rahman. Shah Alam: Fajar Bakti Sdn. Bhd, 2004.

Zainulfaqar Yaacob. "ADUN Pandang Serius Wabak Denggi”, Buletin Mutiara, edisi 16-31 Januari 2014.

Zakaria Awang Soh. Kejadian dan Keadaan Alam Semesta. Kuala Lumpur: Berita Publishing Sdn. Bhd, 1990. 